\title{
Resim-İş Öğretmenliği Lisans Derslerinin Meslek Hayatına Katkısına Yönelik Öğretmen Görüşleri
}

\author{
The Views of the Teachers about the Contribution of the Art Teaching \\ Undergraduate Courses to Professional Life
}

\section{Fatih Karip}

Dr. Öğr. Üyesi, Ağrı İbrahim Çeçen Üniversitesi, Eğitim Fakültesi, Güzel Sanatlar Eğitimi Bölümü email: fkarip@agri.edu.tr (DORCID ID: https://orcid.org/0000-0002-8957-1568

\section{Atıf (APA 6)/To cite this article}

Karip, F. (2019). Resim-İș öğretmenliği lisans derslerinin meslek hayatına katkısına yönelik öğretmen görüşleri. Atatürk Üniversitesi Güzel Sanatlar Enstitüsü Dergisi, 43, 9-19. doi: https://doi.org/10.32547/ataunigsed.575018

Makale Gönderim Tarihi/Received: 10/06/2019

Makale Kabul Tarihi/Accepted: 27/09/2019

Makale Yayın Tarihi/Published: 26/10/2019

Research Article/Araştırma Makalesi

$\ddot{O} z$

Yüksek Öğretim Kurulu'nun son yayımladı̆̆ üç programın ders ve kredi sayıları Alan Eğitimi, Meslek bilgisi ve Genel kültür bakımından programa olan katkıları incelendiğginde alan eğitimini olusturan derslerin, ders sayılarının ve kredilerinin giderek azaldığını görmekteyiz. Bu çalıșma amacı Resim İs Öğretmenliği programında yer alan, Alan Eğitimi, Meslek Bilgisi ve Genel Kültür derslerinin programdaki yükleri ve öğretmenlik mesleğine olan katkılarını öğretmen görüşlerine göre incelemektir. Araștırmaya Ağrı ili ve ilçelerinde 2018-2019 eğitim öğretim y1lında görev yapan 104 görsel sanatlar öğretmeni katılmıștır. Çalışmada Nicel araştırma yaklaşımlarından tarama yöntemi kullanılmıstır. Calıșmada veri toplama aracı olarak Resim is öğretmenliği Lisan Programını oluşturan tüm dersler, öğretmenlere her bir dersin meslek hayatına yaptığı katkıyı soran 5'li liket tipi bir ölçeğe dönüștürülerek elde edilmiștir. Lisans programında bulunan dersler lisans programı kapsamında belirtilen alan eğitimi, meslek bilgisi ve genel kültür olmak üzere üç ana bölüme ayrılmıştır. İlgili veri seti kullanılarak her bir dersin hangi alana girdiğine yönelik faktör analizi yapılmıştır. Faktör analizlerine göre ilgili derslerin Resim İs Öğretmenliği lisans programında belirtildiği gibi üç bölüm altında toplandığı görülmüstür. Bu bağlamda ilgili derslerin toplandığı bölümlerin toplam puanı alınarak bağımsız örneklemler $t$ testi ve tek yönlü ANOVA analizleri yapılmıștır. Buna göre Resim is Öğretmenliği lisans programında okutulan alan eğitimi, meslek bilgisi ve genel kültür derslerinin öğretmenlerin meslek hayatına katkısının cinsiyete göre istatistiksel olarak anlamlı olmadığı görülürken, görev yaptığı okullara ve mesleki tecrübeye göre anlamlı olarak farklılaştığı ortaya çıkmıștır. Buna göre ortaokul ve güzel sanatlar liselerinde görev yapan öğretmenlerin ve görev süresine göre daha tecrübeli öğretmenlerin alan eğitimi derslerinin meslek hayatına daha fazla katkı sağladığına yönelik düşünceleri istatistiksel olarak anlamlı bulunmuştur.

Anahtar Kelimeler: Resim İş Öğretmenliği, Lisans Programı, Alan Eğitimi, Öğretmen Görüşleri

\begin{abstract}
When the number of courses and credits of the three curriculums recently published by the Council of Higher Education and their contribution to the curriculum are examined in terms of Field Education, Professional Knowledge and General Culture, we see that the courses, the number of the courses and credits that constitute the field education are gradually decreasing. The aim of this study is to examine the course loads of the field education, professional knowledge and general culture courses in the curriculum and their contributions to the teaching profession according to the teachers' opinions. 104 visual arts teachers working in Agr1 province and districts in 2018-2019 academic year participated in the study. In the study, survey method which is one of the quantitative research approaches was used. In the study, the data was obtained by transforming all the courses that constitute the undergraduate program of Art Teaching into a 5likert scale asking teachers the contribution of each course to their professional life. The courses in the undergraduate program were divided into three main sections: field education, professional knowledge and general culture. Using the relevant data set, factor analysis was conducted for the field in which each course included. According to factor analysis, it was seen that the related courses are grouped under three sections as indicated in the undergraduate program of art teaching. In this context, independent samples $t$ test and one-way ANOVA analysis were done by taking the total score of the departments in which the related courses were included. Accordingly, it was seen that the contribution of the field education, professional knowledge and general culture courses taught in the Bachelor of Arts Teaching program to the professional life of the teachers was not statistically significant in terms of gender, however, it was found out that it differs significantly in terms of the schools they work and their professional experience. According to this, it was determined that the opinions of the teachers working in secondary and fine arts high schools and the more experienced teachers according to their term of duty that the field education courses contribute more to the professional life were statistically significant.
\end{abstract}

Keywords: Art Education, Undergraduate Program, Teacher Opinions

\section{Giriș}

Öğretmenlik mesleği, 1739 sayılı Milli Eğitim Temel Kanununda “Öğretmenlik, devletin eğitim, öğretim ve bununla ilgili yönetim görevlerini üzerine alan özel bir ihtisas mesleğidir. Öğretmenler bu görevlerini Türk Milli Eğitiminin amaçlarına ve temel ilkelerine uygun olarak ifa etmekle yükümlüdürler. Öğretmenlik mesleğine hazırlık genel kültür, özel alan eğitimi ve pedagojik formasyon ile sağlanır.” seklinde tanımlanmıştır (MEB, 1973). Özellikle rekabet ortamının giderek arttığı günümüzde nitelikli bireyler yetiştirmek açısından öğretmen yetiştirme 
programları ve eğitim sisteminin en önemli bileşenlerinden biri olan öğretmenler son derece önemlidir. Ülkelerin nitelikli öğretmen gücü, ekonomik, toplumsal ve bilimsel alanlarda gösterdikleri bilimsel ilerlemeyi doğrudan etkilemektedir. Bu nedenle gelișmiş ülkelerin öğretmen yetiștirmedeki öncelikli hedefi nitelikli öğretmen yetiştirme programlarını geliştirmek olmuştur. Nitelikli öğretmen yetiştirme idealinin gerçekleşmesi adına, öğretmen yetiştirme lisans programları yeniden gözden geçirilerek bahsedilen eksikliklerin giderilmesi mutlaka gerekmektedir (Şişman, 2017, s. 1304).

Öğretmenlik Mesleği Genel Yeterlikleri, Eğitim fakültelerinin öğretmen yetiştirmeye yönelik Programlarında yer alan derslerin içeriklerinin belirlenmesinde önemli bir yol gösterici olarak kullanılmaktadır. Böylece öğretmenlik mesleğine kaynak teşkil eden bölümlerdeki öğrencilere yeterlikler kapsamında belirlenmiş olan bilgi, beceri, tutum ve değerler kazandırılabilecek ve eğitim öğretim sistemimizde yer alacak öğretmenlerimizin yetkinlikleri arttırılacaktır. Öğretmenlik Mesleği Genel Yeterlikleri, her bir öğretmenin kendi alanına ilişkin yeterliklerini de kapsayacak mahiyette, birbiriyle ilişkili ve birbirini tamamlayan mesleki bilgi, mesleki beceri, tutum ve değerler olmak üzere 3 yeterlik alanı ve bu alanlar altında yer alan 11 yeterlik ve bu yeterliklere ilişkin 65 göstergeden oluşmaktadır (MEB, 2017). Öğretmenlerin niteliğiyle ilgili bu tanımlamalar, sadece bir kontrol ve hesap verme aracı değildir. Aynı zamanda bu süreçte öğretmenlerin mesleki gelişme ve eğitiminin önemli göstergelerinden biridir (Şişman, 2009, s. 68). Öğretmen niteliklerinin iyileştirilmesine yönelik, 10. Kalkınma planı, 2017 yılı Öğretmen Strateji Belgesi, Milli Eğitim şuralarında alınan kararlar, Uluslararası kurum ve kuruluşların yapmış oldukları çalışmalar, sempozyum, çalıştay ve kongrelerden oluşan bilimsel etkinlikler gibi pek çok tavsiye ve çalışma metni bulunmaktadır. Tüm bu çalışmaların ışığında yeni programlar, başta eğitim fakülteleri olmak üzere, talim terbiye kurulu çalışanları ve akademisyenlerin olduğu çalıştaylar sonunda oluşturulmaktadır (YÖK, 1998; YÖK, 2007; YÖK, 2018). Bu çalışmaların yürütülmesinde yalnızca akademisyenlerin değil başta öğretmenler olmak üzere öğretmenlikle ilgili tüm paydaş gurupların katılımı önem arz etmektedir.

Nitelikli öğretmen yetiştirme konusunu tarihsel olarak incelediğimizde ilk kez, öğreteceği konuları bilen değil, onları nasıl etkili biçimde öğreteceğinin bilimsel yöntemleri ve bazı meslek dersleri de kendisine öğretilmeye çalışılmış öğretmen modeli 1848 'den itibaren, yani Tanzimat döneminde ortaya çıkıp şekillenmeye başlamıştır (Akyüz, 2006, s. 18). Ülkemizde 1982 yılına kadar Millî Eğitim Bakanlığı'na bağlı okulların bünyesinde olan öğretmen yetiştirme programları, bu tarihten sonra Üniversitelere devredilmiştir. Yüksek öğretmen okulları ve eğitim enstitüleri gibi kurumlar bünyesinde yer alan öğretmen yetiştirme programları, eğitim/eğitim bilimleri fakülteleri ile bir süre sonra eğitim fakültelerine dönüșen eğitim yüksekokulları içinde yeniden yapılandırılmıştır (YÖK, 2018). Yüksek Öğretim Kurumu ve Dünya Bankası'nın 1994-1997 yılları arasında yürüttüğü Milli Eğitimi Geliștirme Projesi kapsamında öğretmen yetiştiren eğitim fakültelerinin yeniden yapılanması çalışmaları başlamışıtır. Bu yapılanma ile yeni eğitim fakülteleri programları 1998-1999 öğretim yılından itibaren uygulamaya konmuştur. Yüksek Öğretim Kurulu 1998 yılından itibaren Eğitim Fakültelerinde yeniden yapılanma sürecini başlatmış ve bu çerçevede yeni düzenlenen öğretmen yetiştirme programlarını uygulamaya koymuştur. 1998 yılında başlattı̆̆ bu yapılanma sürecinde, 1998, 2007 ve 2018 yılları olmak üzere 3 farklı program yayımlamıştır.

$\mathrm{Bu}$ çalışma açısından tartışma konusu olan husus Resim İş Öğretmenliği programında yer alan, Alan Eğitimi, Meslek Bilgisi ve Genel Kültür derslerinin programdaki yükleri ve öğretmenlik mesleğine olan katkıları olacaktır. Son yayımlanan 3 programın ders ve kredi sayıları alan eğitimi, meslek bilgisi ve genel kültür bakımından programa olan katkıları incelendiğinde aşağıdaki tablodaki gibi bir sonuç çıkmaktadır.

Tablo 1

Resim iş öğretmenliği programı lisans derslerinin alan eğitimi, meslek bilgisi ve genel kültür alanlarına göre dağılımları

\begin{tabular}{|c|c|c|c|c|c|c|c|c|c|c|c|c|}
\hline \multirow{3}{*}{ Ders Alanları } & \multicolumn{4}{|c|}{1998} & \multicolumn{4}{|c|}{2007} & \multicolumn{4}{|c|}{2018} \\
\hline & \multicolumn{2}{|c|}{ Ders sayısı } & \multicolumn{2}{|c|}{ Kredi sayısı } & \multicolumn{2}{|c|}{ Ders sayısı } & \multicolumn{2}{|c|}{ Kredi sayısı } & \multicolumn{2}{|c|}{ Ders sayısı } & \multicolumn{2}{|c|}{ Kredi sayısı } \\
\hline & $n$ & $\%$ & n & $\%$ & $n$ & $\%$ & n & $\%$ & $n$ & $\%$ & n & $\%$ \\
\hline Alan Eğitimi & 126 & 65,6 & 97 & 66,5 & 108 & 56 & 80 & 52 & 102 & 55 & 78 & 50 \\
\hline Genel Kültür & 18 & 9,4 & 13 & 9 & 40 & 21 & 37 & 24 & 28 & 15 & 27 & 17 \\
\hline Toplam & 192 & 100 & 146 & 100 & 192 & 100 & 154 & 100 & 186 & 100 & 155 & 100 \\
\hline
\end{tabular}

Tablo 1 incelendiğinde 1998 yılından 2018 yllına doğru alan eğitimi derslerinin, ders saatlerinin ve kredilerinin giderek azaldığı görülmektedir. Meslek bilgisi derslerinin ders sayılarının ve kredilerinin 2007 yılında değişmediği, 2018 yılında arttığı; Genel kültür derslerinin ise 2007 yılında arttığı, 2018 y1lında bir önceki programa göre azaldığı görülmektedir. Buna göre bu süreçten en fazla etkilenen derslerin alan eğitimini oluşturan dersler olduğunu söylenebilir. Bununla birlikte 2007 yılında yayımlanan programda birtakım karışıklıkların olduğu söylenebilir. Meslek bilgisine ait olması gereken bazı derslerin alan eğitimi kategorisinde (Özel Öğretim Yöntemleri); Alan eğitimi kategorisinde olması gereken bazı derslerin de genel kültür bölümünde (Batı Sanatı Tarihi, Sanat Eleştirisi) bulunduğu görülmektedir. Bu yanlışlık derslerin alan eğitimi, meslek bilgisi ve genel kültür dağılımlarını da etkilemektedir (Küçükahmet, 2007, s. 207). 
Uygulanan öğretmen yetiştirme programının nihai amacının sahada öğretmenlerin kullanabilecekleri, öğrencilere faydalı, öğretilebilir, gerçek hayata bakan bir yanının olması gerekmektedir. Bu bakımdan öğretmen görüşleri öğretim programlarının güncellenmesinde bir veri kaynağı olarak önemli bir yere sahip olduğu düşünülmektedir. İlgili literatür incelendiğinde Resim iş Öğretmenliği Lisans programının meslek hayatına ne derece katkı sağladığına yönelik görsel sanatlar öğretmenlerinin düşüncelerini yansıtan bir çalışmanın olmadığı görülmüştür. Bu bakımdan bu çalışma hem 2018 yılında yayımlanan güncel programı değerlendirmek hem de literatürde eksik olan bu boşluğu dolduracağından önemli olduğu düşünülmektedir. Bu kapsamda aşağıdaki araştırma sorularının cevapları aranmıştır:

1. Resim İş Öğretmenliği Lisans Programında yer alan, alan eğitimi, meslek bilgisi ve genel kültür derslerinin meslek hayatına katkısına yönelik öğretmen görüşleri cinsiyete göre değişmekte midir?

2. Resim İş Öğretmenliği Lisans Programında yer alan, alan eğitimi, meslek bilgisi ve genel kültür derslerinin meslek hayatına katkısına yönelik öğretmen görüşleri Görev yaptığı okul türüne göre değişmekte midir?

3. Resim İş Öğretmenliği Lisans Programında yer alan, alan eğitimi, meslek bilgisi ve genel kültür derslerinin meslek hayatına katkısına yönelik öğretmen görüşleri mesleki tecrübeye göre değişmekte midir?

\section{Yöntem}

Bu çalışmada nicel araştırma yaklaşımlarından tarama araştırması kullanılmıştır. Nicel araştırmalar gözlenebilen, ölçülebilen somut gerçeklikler üzerine kurulmuştur. Temelinde mantık ve matematik vardır. Veriler mantığa uygun olmalı ve matematik diline, sayılara çevrilerek ifade edilmelidir (Sönmez ve Alacapınar, 2011, s.40) Tarama araştırmaları, geniş bir grubun çeşitli özelliklerini belirlemek için verilerin toplanmasını amaçlayan çalışmalardır. Tarama araştırmalarında temel amaç, mevcut durumu olduğu gibi ortaya koymaya çalışmaktır çalışmalardır (Büyüköztürk, Çakmak, Akgün, Karadeniz ve Demirel 2013, s. 177).

\section{1. Çalışma grubu}

Çalışmanın veri seti Ağrı ili ve ilçelerinde görev yapmakta olan görsel sanatlar öğretmenlerinden oluşmaktadır. İlgili veri seti 2018-2019 eğitim öğretim yılının bahar döneminde bir aylık süre içerisinde yüz yüze görüşülerek toplanmıştır. Veri setine ilişkin demografik bilgiler Tablo 2'de verilmiştir.

Tablo 2

Görsel sanatlar öğretmenlerinin sosyo demografik bilgilerine ilişkin frekans ve yüzdeleri

\begin{tabular}{|c|c|c|c|}
\hline Değişkenler & Değişken düzeyleri & Frekans (f) & Yüzde (\%) \\
\hline \multirow{2}{*}{ Cinsiyet } & Kadın & 38 & 36.54 \\
\hline & Erkek & 66 & 63.46 \\
\hline \multirow{3}{*}{ Görev Yeri } & Ortaokul & 59 & 56.73 \\
\hline & Lise & 25 & 24.04 \\
\hline & Güzel sanatlar lisesi & 20 & 19.23 \\
\hline \multirow{4}{*}{ Mesleki Denetim/ Tecrübe } & $1-5$ y1l arası & 47 & 45.20 \\
\hline & $6-10$ y1l arası & 28 & 26.92 \\
\hline & 11 y1l ve üstü & 28 & 26.92 \\
\hline & Kayıp veri & 1 & 0.96 \\
\hline Toplam & & 104 & 100 \\
\hline
\end{tabular}

Tablo 2 incelendiğinde, Görsel Sanatlar Dersi öğretmenlerinin büyük çoğunluğunun erkek olduğu ve çoğunlukla ortaokulda çalıştıkları görülmektedir. Meslekteki deneyimlerine bakıldığında öğretmenlerin yarısının 1 ile 5 yıllık bir tecrübeye sahip oldukları diğerlerinin ise altı yıl ve üstü oldukları görülmektedir.

\subsection{Veri toplama aracı}

Güzel Sanatlar Eğitimi Bölümü Resim İş Öğretmenliği Lisans Programında dört yıllık eğitim boyunca okutulan lisans dersleri baz alınarak çalışmanın veri toplama aracı oluşturulmuştur. Bu bağlamda resim iş öğretmenliği programı lisans derslerin sınıflandırılması esas alınarak dersler üç ana bölüme göre düzenlenmiştir. Görsel sanatlar öğretmenlerine lisans programında okutulan her bir dersin meslek hayatına katkısını belirlemek amacıyla ilgili dersler beşli likert ile derecelendirilen anket sorularına dönüştürülmüştür. Tablo 3 'te veri toplamak için oluşturulan ölçeğe yönelik bir örnek verilmiştir. 
Tablo 3

Resim iş öğretmenliği lisans programını oluşturan derslere yönelik öğretmen görüşlerinin elde edildiği veri toplama arac1

Değerli Hocam aşağıdaki anket soruları Güzel Sanatlar Eğitimi Resim Öğretmenliği lisans programı derslerinin meslek hayatına ne ölçüde katkı sağladığını tespit etmek üzere hazırlanmıştır. Vereceğiniz yanıtlar tamamen bilimsel amaçlı kullanılacak olup samimi cevaplarınız çalışmanın güvenirliğine olumlu yönde katkılar sunacaktır. Katkılarınızdan ötürü çok teşekkür ederiz.

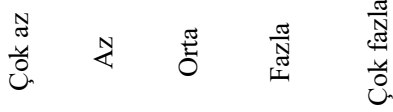

\begin{tabular}{llllll}
\hline AE & Temel Tasarım & 1 & 2 & 3 & 4 \\
MB & Eğitim Bilimine Giriş & 5 & 1 & 2 & 3 \\
\hline GK & Türkçe: Yazılı Anlatım & 4 & 5 \\
\hline
\end{tabular}

Resim iș Öğretmenliği Lisans Programında bulunan dersler lisans programı kapsamında belirtilen alan eğitimi, meslek bilgisi ve genel kültür olmak üzere üç bölüme ayrılmıştır. İlgili veri seti kullanılarak her bir dersin hangi alana girdiğine yönelik faktör analizi yapılmıştır. Faktör analizine geçilmeden önce veri setinde uç değerlerin bulunup bulunmadığı incelenmiş ve herhangi bir uç değerin bulunmadığı görülmüştür. Veri setindeki kayıp veriler için beklenti maksimizasyonu (EM) algoritması kullanılarak kayıp değer ataması yapılmıştır. İlgili sayıltılar test edildikten sonra faktör analizine geçilmiştir. Yapılan faktör analizinin uygunluğuna karar vermek için KMO ve Bartlett küresllik testinden faydalanılmıştır. Alan eğitimi, meslek bilgisi ve genel kültür dersleri için yapılan faktör analizlerine ilişkin KMO ve Bartlett küresellik testleri Tablo 4’te verilmiştir.

Tablo 4

KMO ve Bartlett küresellik testleri

\begin{tabular}{|c|c|c|c|c|}
\hline \multirow{12}{*}{ 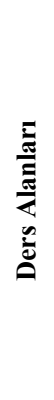 } & \multirow{4}{*}{ Alan Eğitimi } & KMO & -- & .837 \\
\hline & & & Ki kare & 1510.196 \\
\hline & & Bartlett Testi & Serbestlik derecesi & 210 \\
\hline & & & Anlamlılık (p) & .000 \\
\hline & \multirow{4}{*}{ Meslek Bilgisi } & KMO & -- & .881 \\
\hline & & & Ki kare & 731.759 \\
\hline & & Bartlett Testi & Serbestlik derecesi & 45 \\
\hline & & & Anlamlılık (p) & .000 \\
\hline & \multirow{4}{*}{ Genel Kültür } & KMO & -- & .805 \\
\hline & & & Ki kare & 389.529 \\
\hline & & Bartlett Testi & Serbestlik derecesi & 15 \\
\hline & & & Anlamlllık (p) & .000 \\
\hline
\end{tabular}

Tablo 4 incelendiğinde; alan eğitimi, meslek bilgisi ve genel kültür derslerinin faktörleşebilir yapıda olduğu görülmektedir. Tüm varsayımlar yapıldıktan sonra faktör analizine geçilmiştir. Her bir ders alanı için yapılan faktör analizine ilişkin sonuçlar ve saçılma diyagramları sırasıyla verilmiştir. İlk olarak alan eğitimine yönelik yapılan faktör analizi sonuçları Tablo 5'de ve saçılma diyagramı şekil 1'de verilmiştir.

Tablo 5

Alan eğitimi için yapılan açımlayıcı faktör analizi sonuçları

\begin{tabular}{|c|c|c|c|c|c|}
\hline Dersin adı & $\begin{array}{c}\text { Faktör } \\
\text { yükü }\end{array}$ & $\begin{array}{c}\text { Ortak } \\
\text { varyans }\end{array}$ & Dersin adı & $\begin{array}{c}\text { Faktör } \\
\text { yükü }\end{array}$ & $\begin{array}{c}\text { Ortak } \\
\text { varyans }\end{array}$ \\
\hline Temel Tasarım & .582 & .339 & İnsanın Sanatsal Gelişimi & .671 & .451 \\
\hline Desen & .566 & .320 & Özel Öğretim Yöntemleri & .649 & .422 \\
\hline Perspektif & .681 & .464 & Sanat Eleştirisi & .715 & .511 \\
\hline Sanat Tarihine Giriş & .665 & .442 & Sanat Felsefesi & .617 & .380 \\
\hline Anasanat Atölye & .554 & .307 & Çağdaş Dünya Sanatı & .685 & .469 \\
\hline Seçmeli Sanat Atölye & .469 & .220 & Türk Sanatı Tarihi & .681 & .463 \\
\hline Seçmeli Sanat Atölye & .472 & .223 & Çağdaş Türk Sanatı & .657 & .432 \\
\hline Seçmeli Sanat Atölye & .670 & .449 & Sanat Öğretimi Uygulamaları & .772 & .596 \\
\hline Yaz1 & .476 & .227 & Sanat Öğretimi Deneyimi & .536 & .287 \\
\hline Batı Sanatı Tarihi & .691 & .477 & Müze Eğitimi & .593 & .352 \\
\hline Çocuk Resmi Psikolojisi & .615 & .379 & & & \\
\hline
\end{tabular}

Acıklanan Varyans Yüzdesi \%39.09

Tablo 5 incelendiğinde, alan eğitimi derslerinin tek bir faktör altında toplandığı ve faktör yüklerinin .469 ile .772 arasında değiştiği görülmektedir. Faktör yükü .30 ve altında olan herhangi bir ders olmadığı için güzel sanatlar lisans programında okutulan derslerin alan eğitimindeki başarıya katkı sağladığı söylenebilir. Her bir derse ilişkin ortak varyans (Communalities) değerleri incelendiğinde ise .220 ile .596 aralığında değiştiği görülmüş olup tüm derslerin .10'dan büyük olduğu gözlemlenmiştir. Açıklanan varyans yüzdesine bakıldığında ilgili derslerin alan eğitimindeki değişimin \%39.09'unu açıkladığı görülmektedir. Başka bir değişle ilgili derslerin alan eğitimindeki değişimin hemen hemen yarısını açıkladığı söylenebilir. Alan eğitimine ilişkin yapılan faktör analizinin saçılma diyagramı Şekil 1'de verilmiştir. 


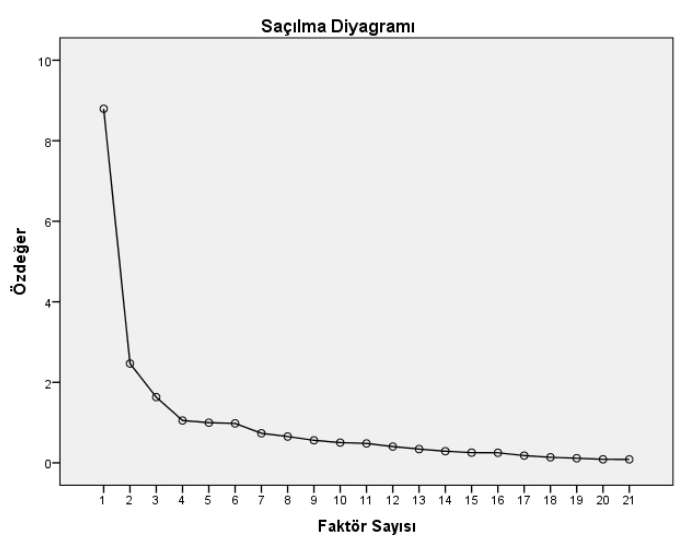

Şekil 1. Alan eğitimi için elde edilen saçılma diyagramı

Şekil 1 incelendiğinde birinci faktörün öz değerinin ikinci faktörün öz değerinden yaklaşık olarak dört kat büyük olduğu görülmektedir. Birinci faktör ile ikinci faktöre ilişkin öz değerler arasındaki fark dikkate alındığında yapının tek faktörlü olduğuna karar verilmiş̧ir (Doğan ve Başokçu, 2010, s. 68).

Alan eğitimine ilişkin faktör analizi yapıldıktan sonra meslek bilgisi derslerine yönelik faktör analizi sonuçları yapılmış ve sonuçlar Tablo 6'da verilmiştir.

Tablo 6

Meslek bilgisi için yapılan açımlayıcı faktör analizi sonuçları

\begin{tabular}{lcc}
\hline Dersin adı & Faktör yükü & Ortak varyans \\
\hline Öğretmenlik Mesleğine Giriş/Eğitim Bilimine Giriş & .739 & .547 \\
Eğitim Psikolojisi & .871 & .759 \\
Ölçme ve Değerlendirme & .702 & .493 \\
Sınıf Yöneyimi & .730 & .872 \\
Rehberlik & .814 & .760 \\
Okul Deneyimi & .749 \\
Öğretmenlik Uygulaması & .781 & .663 \\
Öğretim İlke ve Yöntemleri & .681 \\
Öğretim Teknolojileri ve Materyal Tasarımı & .465 \\
Türk Eğitim Sistemi ve Okul Yönetimi & .562 \\
\hline
\end{tabular}

Açklanan Varyans Yüzdesi \% $\% 6.06$

Tablo 6 incelendiğinde, meslek bilgisi derslerinin tek bir faktör altında toplandığı ve faktör yüklerinin .465 ile .872 arasında değiştiği görülmektedir. Faktör yükü .30 ve altında olan herhangi bir ders olmadığı için Resim iş Öğretmenliği lisans programında okutulan derslerin alan eğitimindeki başarıya katkı sağladığı söylenebilir. Her bir derse ilişkin ortak varyans (Communalities) değerleri incelendiğinde ise .216 ile .760 aralığında değiştiği görülmüş olup tüm derslerin .10'dan büyük olduğu gözlemlenmiștir. Açıklanan varyans yüzdesine bakıldığında ilgili derslerin meslek bilgisindeki değişimin \%56.06'sını açıkladığı görülmektedir. Başka bir değișle ilgili derslerin meslek bilgisindeki değişimin yarısından fazlasını açıkladığı söylenebilir. Meslek bilgisi derslerine ilişkin faktör analizinin saçılma diyagramı Şekil 2'de verilmiştir.

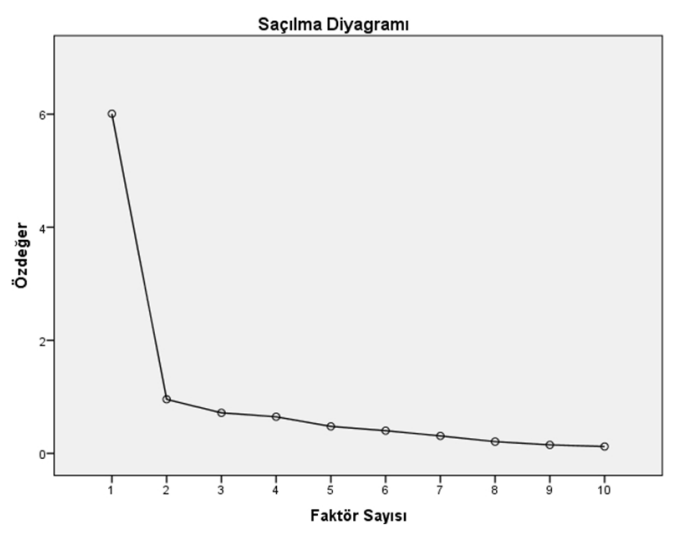

Şekil 2. Meslek bilgisi için elde edilen saçılma diyagramı

Şekil 2 incelendiğinde birinci faktörün öz değerinin ikinci faktörün öz değerinden yaklaşık olarak dört kat büyük olduğu görülmektedir. Buna göre yapının tek faktörlü olduğu görülmektedir. 
Meslek bilgisi derslerine ilişkin faktör analizi yapıldıktan sonra genel kültür derslerine yönelik faktör analizi sonuçları yapılmış ve sonuçlar Tablo 7'de verilmiştir.

Tablo 7

Genel kültür için yapılan açımlayıcı faktör analizi sonuçları

\begin{tabular}{lcc}
\hline Dersin adı & Faktör yükü & Ortak varyans \\
\hline Bilgisayar & .780 & .608 \\
Atatürk İlkeleri ve İnkılap Tarihi & .634 & .401 \\
Yazılı Anlatım & .896 & .804 \\
Sözlü anlatım & .896 & .803 \\
İnilizce & .631 & .398 \\
Topluma Hizmet Uygulamaları & .665 & .443 \\
\hline Açıklanan Varyans Yüzdesi \%57.61 & & \\
\hline
\end{tabular}

Tablo 7 incelendiğinde, Genel Kültür derslerinin tek bir faktör altında toplandığı ve faktör yüklerinin .631 ile .896 arasında değiştiği görülmektedir. Faktör yükü .30 ve altında olan herhangi bir ders olmadığı için Resim iş Öğretmenliğ̣i lisans programında okutulan derslerin Genel kültür eğitimine başarıya katkı sağladığı söylenebilir. Her bir derse ilişkin ortak varyans (Communalities) değerleri incelendiğinde ise .398 ile .804 aralığında değiștiği görülmüş olup tüm derslerin .10'dan büyük olduğu gözlemlenmiştir. Açıklanan varyans yüzdesine bakıldığında ilgili derslerin genel kültür bilgisindeki değişimin \%57.61'ini açıkladığı görülmektedir. Başka bir değişle ilgili derslerin meslek bilgisindeki değişimin yarısından fazlasını açıkladığı söylenebilir. Alan eğitimine ilişkin yapılan faktör analizinin saçılma diyagramı Şekil 3'de verilmiştir.

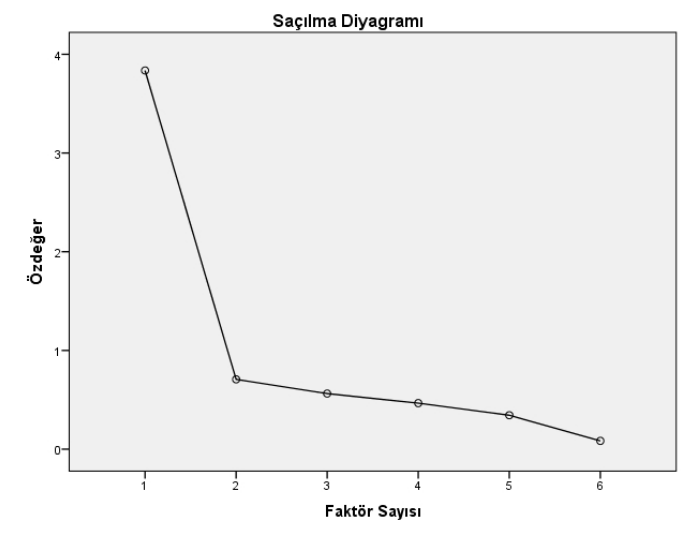

Şekil 3. Genel kültür dersleri için elde edilen saçılma diyagramı

Şekil 3 incelendiğinde birinci faktörün öz değerinin ikinci faktörün öz değerinden yaklaşık olarak dört kat büyük olduğu görülmektedir. Buna göre yapının tek faktörlü olduğu görülmektedir.

Ölçme aracının geçerliğine ilişkin kanıtlar toplandıktan sonra, ölçümlerin güvenirliği için Cronbach alfa katsayısı incelenmiştir. Ölçme aracından elde edilen ölçümlerin güvenirliği için kestirilen değerler Tablo 8'de verilmiştir.

Tablo 8

Resim İş programı ölçeği ve alt faktörlerine ilişkin güvenirlik kestirimleri

\begin{tabular}{lcc}
\hline Ölçek ve alt faktörleri & Cronbach $\boldsymbol{\alpha}$ & Madde sayıs \\
\hline Alan Eğitimi & .865 & 11 \\
Meslek Bilgisi & .923 & 20 \\
Genel Kültür & .882 & 6 \\
Ölçeğin Bütünü & .948 & 37 \\
\hline
\end{tabular}

Tablo 8 incelendiğinde, ölçme araçlarının bütünü ve alt faktörleri için kestirilen güvenirlik değerlerinin kabul edilebilir olduğu görülmektedir.

\subsection{Veri analizi}

Verilerin analizinde açımlayıcı faktör analizi (AFA), bağımsız örneklemler $\mathrm{t}$ testi ve tek yönlü varyans analizi kullanılmıştır. Ölçme aracının yapı geçerliğine kanıt sağlamak amacıyla AFA analizine başvurulmuştur. Daha sonra AFA sonuçlarına dayanılarak toplam puanı alınan ölçme aracının cinsiyete göre istatistiksel olarak farklılaşıp farklılaşmadığını belirlemek amacıyla bağımsız örneklemler t-testi yapılmış̧ır. Öğretmenlerin görev yaptıkları okul türü ve mesleki deneyimlerine göre istatistiksel farklılığı incelemek için tek yönlü ANOVA yapılmıştır. Bağımsız örneklemler t-testi ve tek yönlü ANOVA'nın kullanılması için verilerin normal dağılıma sahip olması gerekir. Yapılan normallik testine ilişkin istatistikler Tablo 9'da verilmiştir. 
Tablo 9

Ölçeğin alt faktörlerine göre normallik testi

\begin{tabular}{lccc}
\hline & Kolmogorov-Smirnov & & \\
\hline & İstatistik & sd & \\
\hline Alan Eğitimi & .064 & 104 & .200 \\
Meslek Bilgisi & .063 & 104 & .195 \\
Genel Kültür & .075 & 104 & .175 \\
\hline
\end{tabular}

Tablo 9 incelendiğinde üç alt faktörün ölçek puanlarının normal dağılım gösterdiği görülmektedir $(p>.05)$. Bu sonuca göre veri analizinde parametrik istatistiklerin kullanılması herhangi bir kestirim hatasına yol açmayacaktır.

Araştırmada ikiden fazla gruba sahip olan okul türü değişkenine yönelik farklılığı ortaya koymak amacıyla çoklu karşılaştırma testleri kullanılmıştır. Çoklu karşılaştırma testine karar vermek için varyansların homojenliği varsayımı Levene Testi ile test edilmiş ve testin sonucu Tablo 10'da verilmiştir.

Tablo 10

Ölçme aracının alt faktörlerine ilişkin varyansların homojenliği testi

\begin{tabular}{lcccc}
\hline & Levene İstatistiği & sd1 & sd2 & p \\
\hline Alan Eğitimi & 2.836 & 2 & 101 & .063 \\
Meslek Bilgisi & 2.563 & 2 & 101 & .075 \\
Genel Kültür & 0.144 & 2 & 101 & .866 \\
\hline
\end{tabular}

Tablo 10 incelendiğinde ölçme aracının üç alt faktöründe de varyansların homojenliği varsayımının karşılandı̆̆ görülmektedir ( $p>.05)$. Varyansların homojenliği sağlandığından çoklu karşılaştırma testi olarak LSD yöntemi tercih edilmiştir.

\section{Bulgular}

\subsection{Birinci alt probleme yönelik bulgular}

Görsel sanatlar öğretmenlerinin lisans programında aldıkları alan eğitimi, meslek bilgisi ve genel kültür derslerinin meslek hayatlarına katkılarının cinsiyete göre farklılaşıp farklılaşmadığını belirlemek amacıyla bağımsız örneklemler t testi yapılmıştır. Yapılan analizin sonuçları Tablo 10'da verilmiştir.

Tablo 11

Görsel sanatlar öğretmenlerinin lisana derslerinin meslek hayatlarına katkısının cinsiyete göre karşılaştırılmasına ilişkin bağımsız örneklemler $\mathrm{t}$ test sonuçları

\begin{tabular}{|c|c|c|c|c|c|c|}
\hline Lisans Ders Grupları & Cinsiyet & $\mathbf{N}$ & $\bar{X}$ & Sd & $\mathbf{t}$ & $\mathbf{p}$ \\
\hline \multirow{2}{*}{ Alan Eğitimi } & Kadın & 38 & 77.77 & \multirow{2}{*}{102} & \multirow{2}{*}{.85} & \multirow{2}{*}{.397} \\
\hline & Erkek & 66 & 80.52 & & & \\
\hline \multirow{2}{*}{ Meslek Bilgisi } & Kadın & 38 & 39.99 & \multirow{2}{*}{102} & \multirow{2}{*}{.71} & \multirow{2}{*}{.478} \\
\hline & Erkek & 66 & 38.66 & & & \\
\hline \multirow{2}{*}{ Genel Kültür } & Kadın & 38 & 19.60 & \multirow{2}{*}{102} & \multirow{2}{*}{.17} & \multirow{2}{*}{.866} \\
\hline & Erkek & 66 & 19.83 & & & \\
\hline
\end{tabular}

Tablo 11 incelendiğinde Resim iș Öğretmenliği Lisans Programında okutulan alan eğitimi, meslek bilgisi ve genel kültür derslerinin öğretmenlerin meslek hayatına katkısının cinsiyete göre istatistiksel olarak anlamlı olmadığ 1 bulunmuştur $(p>.05)$. Başka bir değişle hem erkek hem de kadın öğretmenlere göre ilgili derslerin meslek hayatlarına katkılarının benzer oldukları bulunmuştur.

\section{2. İkinci alt probleme yönelik bulgular}

Resim İş Öğretmenliği Lisans Programında okutulan derslerin öğretmenlerin meslek hayatlarına katkılarının görev yaptıkları okul türüne göre farklılaşıp farklılaşmadığını belirlemek amacıyla tek yönlü varyans analizi yapılmış olup sonuçlar Tablo 12'de verilmiştir.

Tablo 12

Görsel Sanatlar Öğretmenlerin lisans öğrenimi süresince aldıkları derslerin meslek hayatlarına katkılarının okul türüne göre karşılaştırılmasına ilişkin tek yönlü varyans analizinin sonuçları

\begin{tabular}{|c|c|c|c|c|c|c|c|}
\hline Lisans Ders Grupları & Okul türü & $\mathbf{N}$ & $\bar{X}$ & Sd & $\mathbf{F}$ & $\mathbf{p}$ & Fark (LSD) \\
\hline \multirow{3}{*}{ Alan Eğitimi } & Ortaokul & 59 & 82.92 & \multirow{3}{*}{$2-101$} & \multirow{3}{*}{7.03} & \multirow{3}{*}{$.001 *$} & \multirow{3}{*}{$\begin{array}{c}\mathrm{O}>\mathrm{L} \\
\mathrm{GSL}>\mathrm{L}\end{array}$} \\
\hline & Lise & 25 & 69.76 & & & & \\
\hline & GSL & 20 & 81.67 & & & & \\
\hline \multirow{3}{*}{ Meslek Bilgisi } & Ortaokul & 59 & 42.45 & \multirow{3}{*}{$2-101$} & \multirow{3}{*}{10.36} & \multirow{3}{*}{$.000^{*}$} & \multirow{3}{*}{$\begin{array}{c}\mathrm{O}>\mathrm{L} \\
\mathrm{O}>\mathrm{GSL}\end{array}$} \\
\hline & Lise & 25 & 35.05 & & & & \\
\hline & GSL & 20 & 34.54 & & & & \\
\hline \multirow{3}{*}{ Genel Kültür } & Ortaokul & 59 & 20.89 & \multirow{3}{*}{$2-101$} & \multirow{3}{*}{6.01} & \multirow{3}{*}{$.003 *$} & \multirow{3}{*}{$\begin{array}{r}\mathrm{O}>\mathrm{L} \\
\mathrm{GSL}>\mathrm{L}\end{array}$} \\
\hline & Lise & 25 & 16.07 & & & & \\
\hline & GSL & 20 & 20.97 & & & & \\
\hline
\end{tabular}


Tablo 12 incelendiğinde, Resim iş Öğretmenliği Lisans Programında okutulan alan eğitimi derslerinin öğretmenlerin meslek hayatlarına katkılarının okul türüne göre istatistiksel olarak bir farklılaşma meydana getirdiği bulunmuştur $\left(\mathrm{F}_{2-101}=7.03 ; p=.001<.05\right)$.

Çoklu karşılaştırmalar sonucunda, ortaokulda çalışan öğretmenlerin $(\bar{X}=82.92)$ alan eğitimi derslerinin, meslek hayatlarına katkılarının, lisede çalışmakta olan öğretmenlerden $(\bar{X}=69.76)$ daha fazla olduğu bulunmuştur. Ayrıca Güzel sanatlar lisesinde görev yapmakta olan öğretmenlerin $(\bar{X}=81.67)$ alan eğitimi derslerinin, meslek hayatlarına katkılarının, lisede görev yapmakta olan öğretmenlere $(\bar{X}=69.76)$ göre daha fazla olduğu bulunmuştur.

Resim iş Öğretmenliği Lisans Programında okutulan meslek bilgisi derslerinin öğretmenlerin meslek hayatlarına katkılarının okul türüne göre istatistiksel olarak anlamlı olduğu bulunmuştur $\left(\mathrm{F}_{2-101}=10.36 ; p=.000<.05\right)$. Ortaya çıkan bu farklılığın hangi okul türü veya türlerinden kaynaklandığını belirlemek amacıyla çoklu karşılaştırma testlerinden LSD testi kullanılmıştır. Çoklu karşılaştırmalar sonucunda, ortaokulda çalışan öğretmenlerin $(\bar{X}=$ 42.45) meslek bilgisi derslerinin meslek hayatlarına katkılarının lisede çalışmakta olan öğretmenlerden $(\bar{X}=35.05)$ daha fazla olduğu bulunmuştur. Ayrıca ortaokulda görev yapmakta olan öğretmenlerin $(\bar{X}=42.45)$ meslek bilgisi derslerinin meslek hayatlarına katkılarının güzel sanatlar lisesinde görev yapmakta olan öğretmenlere $(\bar{X}=34.54)$ göre daha fazla olduğu bulunmuştur.

Resim iş Öğretmenliği Lisans Programında okutulan genel kültür derslerinin öğretmenlerin meslek hayatlarına katkılarının okul türüne göre istatistiksel olarak bir farklılaşma meydana getirdiği bulunmuştur $\left(\mathrm{F}_{2-101}=6.01\right.$; $p=.003<.05$ ). Ortaya çıkan bu farklılığın hangi okul türü veya türlerinden kaynaklandığını belirlemek amacıyla çoklu karşılaştırma testlerinden LSD testi kullanılmıştır. Çoklu karşılaştırmalar sonucunda, ortaokulda çalışan öğretmenlerin $(\bar{X}=20.89)$ genel kültür derslerinin meslek hayatlarına katkılarının lisede çalıșmakta olan ögretmenlerden $(\bar{X}=16.07)$ daha fazla olduğu bulunmuştur. Ayrıca Güzel sanatlar lisesinde görev yapmakta olan ögretmenlerin $(\bar{X}=20.97)$ genel kültür derslerinin meslek hayatlarına katkılarının lisede görev yapmakta olan öğretmenlere $(\bar{X}=16.07)$ göre daha fazla olduğu bulunmuştur.

Güzel sanatlar lisans programında okutulan derslerin öğretmenlerin meslek hayatlarına katkılarının mesleki tecrübeye göre farklılaşıp farklılaşmadığını belirlemek amacıyla tek yönlü varyans analizi yapılmış olup sonuçlar Tablo 13'de verilmiştir.

\section{3. Üçüncü alt probleme yönelik bulgular}

Tablo 13

Görsel sanatlar öğretmenlerinin lisans öğrenimi süresince aldıkları derslerin meslek hayatlarına katkılarının mesleki tecrübeye göre karşılaştırılmasına ilişkin tek yönlü varyans analizi sonuçları

\begin{tabular}{|c|c|c|c|c|c|c|c|}
\hline Lisans Ders Grupları & Mesleki Tecrübe & $\mathbf{N}$ & $\bar{X}$ & Sd & $\mathbf{F}$ & $\mathbf{p}$ & Fark (LSD) \\
\hline \multirow{3}{*}{ Alan Eğitimi } & $1-5 \mathrm{y} 11$ & 47 & 76.58 & \multirow{3}{*}{$2-100$} & \multirow{3}{*}{4.80} & \multirow{3}{*}{$.010^{*}$} & \multirow{3}{*}{$\begin{array}{l}3>1 \\
3>2\end{array}$} \\
\hline & $6-10$ y1l & 28 & 76.72 & & & & \\
\hline & 11 ve üstü & 28 & 87.17 & & & & \\
\hline \multirow{3}{*}{ Meslek Bilgisi } & $1-5$ y1l & 47 & 37.94 & \multirow{3}{*}{$2-100$} & \multirow{3}{*}{0.80} & \multirow{3}{*}{.452} & \multirow{3}{*}{ Fark yok } \\
\hline & $6-10$ y1l & 28 & 39.34 & & & & \\
\hline & 11 ve üstü & 28 & 40.70 & & & & \\
\hline \multirow{3}{*}{ Genel Kültür } & $1-5 \mathrm{y} 1 \mathrm{l}$ & 47 & 19.34 & \multirow{3}{*}{$2-100$} & \multirow{3}{*}{1.71} & \multirow{3}{*}{.187} & \multirow{3}{*}{ Fark yok } \\
\hline & $6-10$ y1l & 28 & 18.73 & & & & \\
\hline & 11 ve üstü & 28 & 21.64 & & & & \\
\hline
\end{tabular}

Not: $1=1$ ile 5 yıl arası, $2=6$ ile 10 yıl arası, $3=11$ yıl ve üstü

Tablo 13 incelendiğinde, Resim İş Öğretmenliği Lisans Programında okutulan alan eğitimi derslerinin öğretmenlerin meslek hayatlarına katkılarının mesleki tecrübeye göre istatistiksel olarak bir farklılaşma meydana getirdiği bulunmuştur $\left(\mathrm{F}_{2-100}=4.80 ; p=.010<.05\right)$. Ortaya çıkan bu farklılığın hangi okul türü veya türlerinden kaynaklandığını belirlemek amacıyla çoklu karşılaştırma testlerinden LSD testi kullanılmıştır. Çoklu karşılaştırmalar sonucunda, 11 yıl ve üstü tecrübeye sahip öğretmenlerin $(\bar{X}=87.17)$ alan eğitimi derslerinin meslek hayatlarına katkılarının 1 ile 5 yıl arasındaki tecrübeye sahip öğretmenlerden $(\bar{X}=76.58)$ daha fazla olduğu bulunmuştur. Ayrıca 11 yıl ve üstü tecrübeye sahip öğretmenlerin $(\bar{X}=87.17)$ alan eğitimi derslerinin meslek hayatlarına katkılarının 6 ile 10 yıl arası tecrübeye sahip öğretmenlere $(\bar{X}=76.72)$ göre daha fazla olduğu bulunmuştur. Güzel sanatlar lisans programında okutulan meslek bilgisi derslerinin öğretmenlerin meslek hayatlarına katkılarının mesleki tecrübeye göre istatistiksel olarak anlamlı olmadığ bulunmuştur $\left(\mathrm{F}_{2-100}=0.80\right.$; $p=.452>.05)$. Ayrıca Resim İş Öğretmenliği Lisans Programında okutulan genel kültür derslerinin öğretmenlerin meslek hayatlarına katkılarının benzer bir biçimde mesleki tecrübeye göre istatistiksel olarak anlamlı olmadığ 1 bulunmuştur $\left(\mathrm{F}_{2-100}=1.71 ; p=.187>.05\right)$. 


\section{Tartışma ve sonuç}

Yüksek Öğretim Kurumu ve Dünya Bankası'nın 1994-1997 yılları arasında yürüttüğü Milli Eğitimi Geliştirme Projesi kapsamında öğretmen yetiştiren eğitim fakültelerinin yeniden yapılanması çalışmaları başlamıştır. Bu yapılanma ile yeni eğitim fakülteleri programları 1998-1999 öğretim yılından itibaren uygulamaya konmuştur. 1998 ve 2018 yılları arası YÖK üç defa Eğitim Fakültelerinin programlarını güncellemiştir. Buna göre Resim İş Öğretmenliği Programını teşkil eden alan eğitimi, meslek bilgisi ve genel kültür dersleri arasından bu süreçte en fazla alan eğitimi derslerinin sayıları ve kredileri azalmıştır. 2018 yılında yayımlanan programda da alan eğitimi derslerinin azaldığı dikkat çekmektedir. Aynı şekilde Ekinci (2018, s. 46), 2007 yılında güncellenen Resim İş Öğretmenliği Lisans Programında birçok derslerin yer almamasının önemli bir eksiklik olduğunu ifade etmiştir. Öğretmen adaylarının sanatsal alanda uygulama yapabileceği atölye dersleri ile eş zamanlı olarak, sanat tarihi, estetik, eleştiri temelli sanat derslerinin sanat eğitimi programlarında yer almasıyla eğitim öğretim niteliği açısından daha etkili sonuçlar elde edilebilir. Bu bakımdan bu çalışmada Resim İş Öğretmenliği Lisans Programında yer alan, meslek bilgisi, alan eğitimi ve genel kültür derslerinin meslek hayatına olan katkısı öğretmen görüşleri ile incelenmiştir.

Araştırmanın 1. alt probleminde Resim İş Öğretmenliği Lisans Programında yer alan, alan eğitimi, meslek bilgisi ve genel kültür derslerinin meslek hayatına katkısına yönelik öğretmen görüşleri cinsiyete göre değişip değişmediği incelenmiştir. Buna göre resim iş öğretmenliği lisans programında okutulan alan eğitimi, meslek bilgisi ve genel kültür derslerinin öğretmenlerin meslek hayatına katkısının cinsiyete göre istatistiksel olarak anlamlı olmadığı görülmüştür. Benzer bir sonuç ise Durukan ve Maden'in (2011) yürüttüğü Öğretmen adaylarının Türkçe Öğretmenliği Lisans Programına yönelik görüşlerinde cinsiyet değişkenine göre anlamlı bir farklılık bulunmamıştır.

Araştırmanın 2. alt probleminde Resim İş Öğretmenliği Lisans Programında yer alan, alan eğitimi, meslek bilgisi ve genel kültür derslerinin meslek hayatına katkısına yönelik öğretmen görüşleri görev yaptı̆̆ı okul türüne göre değişip değişmediği incelenmiştir. Buna göre ortaokulda çalışan öğretmenlerin $(\bar{X}=82.92)$ alan eğitimi derslerinin meslek hayatlarına katkılarının lisede çalışmakta olan öğretmenlerden $(\bar{X}=69.76)$ daha fazla olduğu bulunmuştur. Ayrıca güzel sanatlar lisesinde görev yapmakta olan öğretmenlerin $(\bar{X}=81.67)$ alan eğitimi derslerinin meslek hayatlarına katkılarının lisede görev yapmakta olan öğretmenlere $(\bar{X}=69.76)$ göre daha fazla olduğu bulunmuştur. Bu sonuçlara paralele olarak Dereobalı ve Ünver (2009) öğretimindeki yeterlik için konu alanındaki yeterliğin ön koşulu olduğunu ifade etmişlerdir. Bu bağlamda düşünecek olursak alan eğitimini oluşturan derslerin öğretmenlerin meslek hayatları boyunca kullanabilecekleri alanla ilgili tüm derslerin bulunması gerekliliğini göstermektedir. Benzer bir şekilde Kırkkılıç ve Maden (2010) güncellenen Türkçe Öğretmenliği lisans programında yer alan, alan derslerinin azaltılmasının programın bir eksikliği olduğu sonucuna ulaşmıştır. Literatürde Resim İş Öğretmenliği lisans derslerinin meslek hayatına katkısına çok fazla çalışmaya rastlanmamıştır. Uğurlu (2013) Öğretmen adayları ile yürüttüğü çalışmasında alan eğitimini Oluşturan derslere yönelik öğretmen adaylarının büyük bir çoğunluğunun (\%70) programın etkililiği açısından olumlu karşıladıkları sonucuna ulaşmıştır. Benzer şekilde farklı branşlarda benzer çalışmalar ve benzer sonuçlar bulunmaktadır. Takıl (2016) Türkçe öğretmenleri ile yürüttüğü çalışmasında benzer şekilde alan eğitimin oluşturan derslerin meslek hayatına önemli katkı sağladığı sonucuna ulaşmıştır.

Bununla birlikte, ortaokulda çalışan öğretmenlerin $(\bar{X}=42.45)$ meslek bilgisi derslerinin meslek hayatlarına katkılarının lisede çalışmakta olan öğretmenlerden $(\bar{X}=35.05)$ daha fazla olduğu bulunmuştur. Ayrıca ortaokulda görev yapmakta olan öğretmenlerin $(\bar{X}=42.45)$ meslek bilgisi derslerinin meslek hayatlarına katkılarının güzel sanatlar lisesinde görev yapmakta olan öğretmenlere $(\bar{X}=34.54)$ göre daha fazla olduğu bulunmuştur. Aynı şekilde ortaokulda çalışan öğretmenlerin $(\bar{X}=20.89)$ genel kültür derslerinin meslek hayatlarına katkılarının lisede çalışmakta olan öğretmenlerden $(\bar{X}=16.07)$ daha fazla olduğu bulunmuştur. Ayrıca güzel sanatlar lisesinde görev yapmakta olan öğretmenlerin $(\bar{X}=20.97)$ genel kültür derslerinin meslek hayatlarına katkılarının lisede görev yapmakta olan öğretmenlere $(\bar{X}=16.07)$ göre daha fazla olduğu bulunmuştur. Bu sonuçları destekler nitelikte Şişman (2017) öğretmen eğitimi programının, öğretmen adaylarına hem etkili öğrenmenin sağlanmasında içerik ve becerilerin düzenlenmesine yönelik olarak, hem de program tasarlama, öğrenme hedeflerini belirleme, öğretimi düzenleme ve değerlendirme konusunda iyi yapılandırılmış öğrenme firsatları sunarak etkin bir model olması gerektiğini ifade etmiştir. Bu doğrultuda günümüzde sadece alanında uzman veya her şeyi çok iyi bilen öğretmen anlayışı değişmiştir. Etkili öğretmen, yeterli alan bilgisinin yanında, uygun öğretim strateji, yöntem ve tekniklerini öğrencilerin bireysel farklılık ve yeterliliklerine göre belirleyen, ölçmenin doğasını ve sınırlılıklarını bilerek değerlendirmesine olabildiğince objektiflik kazandıran, destekleyici sınıf yönetimi anlayışını merkeze alan ve eğitim sürecinin her aşamasında uygun rehberlik davranışlarını sergileyebilmelidir (Çoğaltay, 2015). Bu açıdan Eret (2013) öğretmen adaylarının mesleğe yeteri kadar hazırlanabilmeleri için velilerle ve okuldaki diğer çalışanlarla iletişim kurma, özel eğitime ihtiyaç duyan öğrencilerle çalışabilme ya da farklı koşullarda öğretmenlik yapabilme konularında öğretmen adaylarını eğitmek gerektiğini ifade etmiştir. 
Araştırmanın 3. alt probleminde Resim İş Öğretmenliği Lisans Programında yer alan, alan eğitimi, meslek bilgisi ve genel kültür derslerinin meslek hayatına katkısına yönelik öğretmen görüşleri mesleki tecrübeye göre değişip değişmediği incelenmiştir. Buna göre yapılan çoklu karşılaştırmalar sonucunda, 11 yıl ve üstü tecrübeye sahip öğretmenlerin $(\bar{X}=87.17)$ alan eğitimi derslerinin meslek hayatlarına katkılarının 1 ile 5 yıl arasındaki tecrübeye sahip öğretmenlerden $(\bar{X}=76.58)$ daha fazla olduğunu ifade ettikleri bulunmuştur. Aynı şekilde 11 yıl ve üstü tecrübeye sahip öğretmenlerin $(\bar{X}=87.17)$ alan eğitimi derslerinin meslek hayatlarına katkılarının 6 ile 10 yıl arası tecrübeye sahip öğretmenlere $(\bar{X}=76.72)$ göre daha fazla olduğunu ifade ettikleri bulunmuştur. Bu sonuçlar Resim İș Eğitimi Lisans Programı Sorunlarına Yönelik Değerlendirme Çalıștayında da ifade edilen sonuçlarla aynı doğrultudadır. Buna göre Görsel sanatlar öğretmeni yetiştirme programının en önemli ayağını "Alan Kültürü" dersleri oluşturmaktadır. Bu derslerin seçmeli olarak müfredata konulması sanat eğitimi sürecinde temel alan bilgisinden yoksun bir program uygulanması anlamına gelir ki; bu da sanat eğitimin niteliğinin tartışılır hale gelmesine neden olur. Bu derslerin seçmeli olarak ana bilim dallarının tasarrufuna bırakılmadan zorunlu olarak okutulmasi gerekmektedir (Anonim, 2019).

\section{Kaynakça}

Akyüz, Y. (2006). Türkiye'de öğretmen yetiştirmenin 160. y1lında Darülmuallimîn'in ilk yıllarına toplu ve yeni bir bakış. Osmanlı Tarihi Araştırma ve Uygulama Merkezi Dergisi, 20, 17-58.

Anonim. (2019, Şubat). Resim İş Ĕ̈itimi Lisans Programı Sorunlarına Yönelik Değerlendirme Çalıştayı Sonuç Raporu. Ankara: Gazi Üniversitesi.

Büyüköztürk, Ş., Kılıç Çakmak, E., Akgün, Ö. E., Karadeniz, Ş., \& Demirel, F. (2013). Bilimsel araştırma yöntemleri. Ankara: Pegem Akademi.

Çoğaltay, N. (2015). Eğitim fakültelerinde okutulan öğretmenlik meslek bilgisi derslerinin etkililiğine ilişkin öğrenci görüşleri: nitel bir araştırma. Eğitim ve İnsani Bilimler Dergisi: Teori ve Uygulama, 6(12), 51-66.

Dereobalı, N., \& Ünver, G. (2009). Okulöncesi öğretmenliği lisans programı derslerinin öğretim elemanları tarafından genel bir bakış açısıyla değerlendirilmesi. İnönü Üniversitesi Ĕgitim Fakültesi Dergisi, 10(3), 161-181.

Doğan, N., \& Başokçu, T. O. (2010). İstatistik tutum ölçeği için uygulanan faktör analizi ve aşamalı kümeleme analizi sonuçlarının karşılaştıılması. Eğitimde ve Psikolojide Ölçme ve Değerlendirme Dergisi, 1(2), 6571.

Durukan, E., \& Maden, S. (2011). Türkçe Öğretmeni Adaylarının Türkçe Öğretmenliği Lisans Programına Yönelik Görüşleri, Kastamonu Ĕgitim Dergisi, 19(2), 555-566.

Ekinci, B. (2018, Nisan). 2006 Resim iş eğitimi lisans programından çıkarılan kuramsal derslerin incelenmesi, Çukurova II. Uluslararası Sanat Araştırmaları Sempozyumu'nda sunulan bildiri, Adana.

Eret, E. (2013). An assessment of pre-service teacher education in terms of preparing teacher candidates for teaching (Doktora tezi). YÖK tez veri tabanından erişildi (Tez No: 345158)

Kırkkılıç, H. A., \& Maden, S. (2010). İlköğretim ve lisans programlarındaki değişiklikler sonrasında Türkçe öğretmenliği mesleğinin ve Türkçe eğitimi bölümlerinin durumu. Türklük Bilimi Araștırmaları Dergisi, 27, 477-502.

Küçükahmet, L. (2007). 2006-2007 öğretim yılında uygulanmaya başlanan öğretmen yetiştirme lisans programlarının değerlendirilmesi. Türk Ĕ̆itim Bilimleri Dergisi, 5(2), 203-218.

MEB. (1973). Milli eğitim temel kanunu. Erişim adresi: http://www.mevzuat.gov.tr/MevzuatMetin/1.5.1739.pdf

MEB. (2017). Öğretmenlik mesleği genel yeterlikleri. Ankara: Öğretmen Yetiştirme Genel Müdürlüğü.

Sönmez, V., \& Alacapınar, F. G. (2011). Örneklendirilmiş Bilimsel Araştırma Yöntemleri. Ankara: Anı Yayıncılık.

Şişman, G. T. (2017). Öğretmen yetiştirme lisans programları ders içeriklerinde "eğitim programı" kavramı. İlköğretim Online, 16(3), 1301-1315.

Şişman, M. (2009). Öğretmen yeterlilikleri: modern bir söylem ve retorik. İnönü Üniversitesi Eğitim Fakültesi Dergisi, 10(3), 63-82.

Takıl, N. B. (2016). Türkçe öğretmenlerinin lisans eğitiminde aldıkları derslerin meslek hayatına etkisi. Akademik Sosyal Araştırmalar Dergisi, 4(29), 373-383.

Uğurlu, S. (2013). Türkiye'de sanat eğitiminde ögretmen yetiștirmeye genel bir bakış (Yüksek Lisans Tezi). YÖK tez veri tabanından erişildi (Tez No. 333895). 
Fatih Karip

Resim İș Öğretmenliği Lisans Derslerinin Meslek Hayatına Katkısına Yönelik Öğretmen Görüşleri

YÖK. (1998). Eğitim Fakültesi Öğretmen Yetiştirme Lisans Programları. Ankara.

YÖK. (2007). Eğitim Fakültesi Öğretmen Yetiştirme Lisans Programları. Ankara.

YÖK. (2018). Öğretmen Yetiştirme Lisans Programlart. Ankara. 